\title{
SONDERJYDSKE ÅR
}

I. halvbind

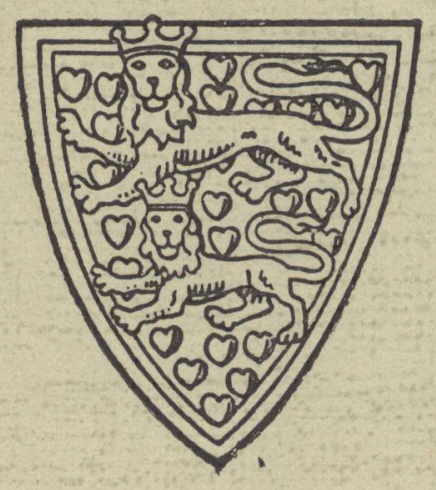

1956

Udgivet af

Historisk samfund for Sonderjylland 


\section{Årsmodet}

Årsmodet afholdes søndag d. 27. maj kl. 13,30 paa Hotel Dybbel Banke, Dybbel.

Dagsorden: 1) Beretning, 2) regnskab, 3) beretning og regnskab for Sønderjyảsk månedsskrift, 4) valg, 5) kontingentets fastsættelse, 6) eventuelt.

Efter Ârsmødet taler professor, dr. phil. Troels Fin k, Århus, om den kirkelige sproggrænse. Rundgang i skanseanlægget under ledelse af fhv. museumsinspektør J. $R$ a b e $n$ og fhv. postmester M. O. Ræd e r, Sønderborg. Fælles kaffebord.

\section{Styrelsen.}

\section{Skaf os flere medlemmer!}

Nyorganiseringen af Historisk samfund har medfort en oget tilgang af nye medlemmer, men såfremt de store og vigtige opgaver, som venter forude, skal kunne løses, må medlemstallet sættes yderligere $i$ vejret. Styrelsen beder derfor hver enkelt tillidsmand og hvert enkelt medlem være med i medlemshvervningen. Det er ikke uoverkommeligt for hvert af foreningens ca. 1300 medlemmer at skafie blot et nyt mediem. Henled venners og bekendtes opmærissomhed på foreningens mangeartede virksomhed, vis dem Sønderjydske årbøger og vore andre publikationer og fortæl dem, at trods stigende priser er kontingentet stadig kun kr. 7,50 + porto.

Som en lille opmuntring for vore hververe er der udsat tre bogpræmier til dem, der tegner flest nye medlemmer inden 1. maj 1957. Den, der tegner de fleste nye medlemmer, kan frit vælge for et beløb på $50 \mathrm{kr}$. af vore publikationer, den næstbedste hverver for $30 \mathrm{kr}$. og den trediebedste for $20 \mathrm{kr}$. For at komme i betragtning ved præmieuddelingen, der vil finde sted på årsmødet 1957, må man dog have tegnet mindst fem nye medlemmer. Styrelsens medlemmer deltager ikke i konkurrencen.

Indmeldelserne bedes sendt til kassereren, fuldmægtig Olav Christensen, Christiansfeldvej 30, Haderslev eller til sekretæren, arkivar Peter Kr. Iversen, Kystvej 10, Ábenrå. 